\title{
The Pontoon Bridge At Marquette
}

\author{
by Anita Lindeman \\ MCGregor, IowA
}

The end of a romantic era in Iowa transportation is recorded in the picture below which was taken at 9:45 A.M. on October 31, 1961 as the pontoon bridge across the Mississippi between Marquette, Iowa, and Prairie du Chien, Wisconsin, carried the last Milwaukee Railroad train. Later that day a crew began removing the tracks, and two days later tugboats removed the 275-foot long pontoon section. Now the trains cross the river at Savanna, Illinois, and LaCrosse, Wisconsin.

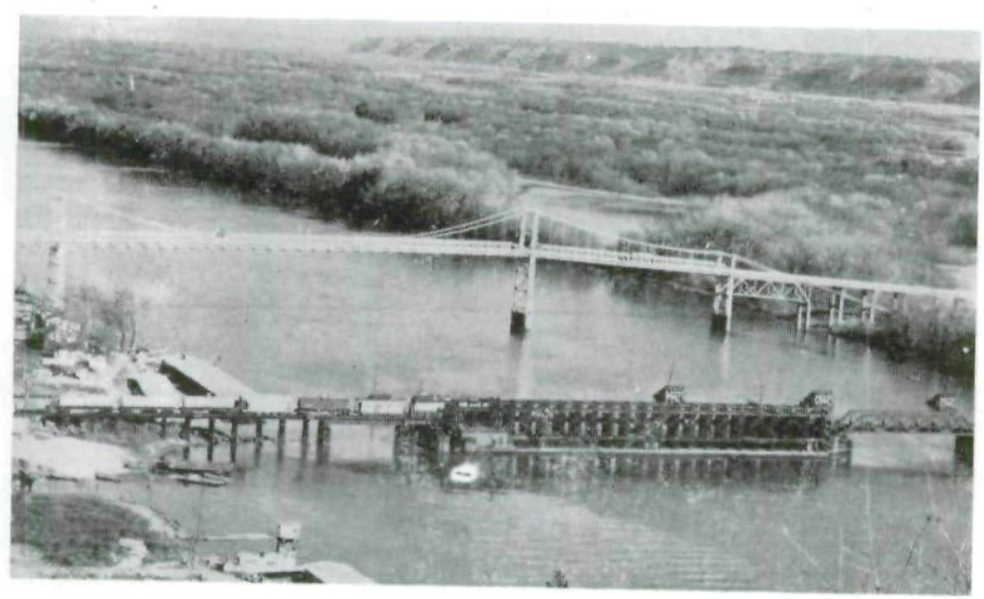

Photo by Anita Lindeman

This famous bridge was invented by a German immigrant named Mike Śpettle, an employee of the late John D. Lawler, and was erected in 1874 by a shipbuilder named Kaukee, of the Rock Island ship yards,

The Milwaukee and Mississippi railway had been completed to Prairie du Chien, Wis., in April, 1857. Prairie du Chien being the upper-most boat landing on the Upper Mississippi at that time, it was here where all the French and Canadian traders of that area came for their supplies and to exchange their game, furs and produce for the 
necessities of life. Immediately after the completion of the railroad, thousands of immigrants swarmed to the fertile lands of Iowa and Minnesota, advertised by the road, and this city for a time was the most important place in the Northwest.

It became necessary to build a road to St. Paul, and a company was organized which pushed the line through a few years later, as it did also to the West. The spanning of the Mississippi, however, was the greatest problem confronting the railroad.

The first summer, freight and passengers were conveyed to the Iowa side by boat, to a point about six miles above North McGregor which at that time was known as the "Red House Landing"; and thousands of western homeseekers and their luggage were unloaded in that narrow ravine, which in later years has been known as "Worth's Landing." In the winter transferring was done over the ice with sleds and teams.

The next summer a rail line had been extended west from North McGregor (now Marquette) to Calmar, and John Lawler conceived the idea of transferring railroad cars by boat. Accordingly, he secured several long barges on which rails were laid down the center and each carried four cars which were run over aprons. A barge was then made fast on either side of a steamboat and towed across the channel and unloaded on the opposite shore. The steamers Allamakee, McGregor and the Janice Brown were used for this purpose. This, however, was slow and the following winter Lawler built a pile bridge and used the barges in the channel. This, too, was inconvenient because of the tremendous river traffic. which was pushing to the north.

In the three years Spettle had been in Lawler's employ he had drafted the pontoon, which, when put into active use, was the marvel of civil engineers and master workmen the world over. The entire length of the bridge was 8,000 feet, crossing both channels of the Mississippi and an intervening island. It was constructed in two parts-the pile or stationary part and the pontoon or movable part consisting of two floating "draws," one in each channel of the Mississippi (on 
the Iowa and Wisconsin side) which, when closed formed an unbroken track, permitting safe and rapid transfer of trains; and when open afforded a clear space of 408 feet in either channel, allowing the midwest rafts and largest tows that float the river to pass with ease and safety.

The pile part of this bridge was of the ordinary construction used by railways. The "draw" over each channel consisted of one pontoon 408 feet long. When they were new (the life of a pontoon is only fourteen years) the "draws" had great buoyancy and strength, being provided with a truss through their entire length. When trains passed over them the draft was increased to eighteen inches. The extreme rise and fall of the river at this point is twenty-one feet and to overcome the variation in the height of the places between the pile bridge and the pontoon, aprons or movable tracks were provided, which were adjusted by means of powerful hydraulic jacks and movable blocks operated by the men in charge. The connection between these aprons and the track of the bridge was a simple device, counterbalanced by equal weights, so that one man clamped and unclamped the end of the pontoon when it swung in and out of position. The pontoons opened in one minute and closed against the current in three minutes, without showing any undue strain, or requiring the application of more than five horse power. The openings in this bridge, up to a few years ago, were the only ones on the Mississippi wide enough to permit a steamer and large rafts to pass through in one section.

During the first forty years in which this famous old bridge had been in use, it was estimated that nearly $1,250,000,000$ cars passed over it. Until 1892, it was owned and operated by John D. Lawler and his sons who taxed the railroad $\$ 1$ for every car that was hauled over it. Lawler died on February 4,1891 , and the following year the property was turned over to the Chicago, Milwaukee and St. Paul Railroad by his estate.

The reason this style of structure is being abandoned is the fact that floating ice each fall and spring had tied up traffic from two or three days to as long as three weeks, according to the amount of ice in the river. The first week in 
November, 1961, the Milwaukee road moved the west span of the rail crossing, which was pushed to LaCrosse, Wis., for further dismantling. The pontoon bridge is now entirely removed.

The picture below, showing one of the last paddle wheel barges-the Alexander Mackenzie-going through the pontoon bridge at Marquette, was taken in 1950 with a Roloflex camera. From the 2 inch square negative, a 5 foot by 12 foot mural was made, purchased by Collins Radio of Cedar Rapids in 1954 and given to the McGregor Public Library last year.

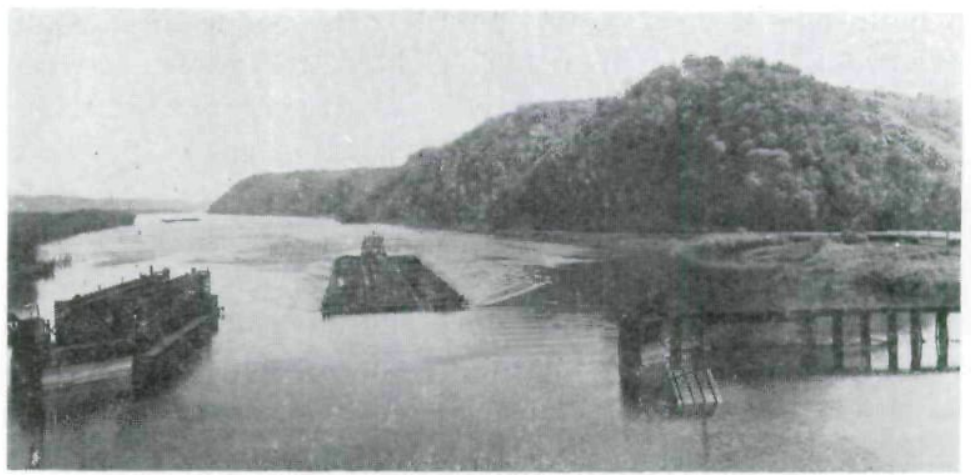

Photo by Gordon Lord

From the THE BEE, Algona, Iowa, 1861

NOTICE

A meeting of the citizens of Kossuth, Palo Alto, and Hancock Counties at the Town Hall in Algona on the 1st day of April 1861, to take into consideration the propriety of seceding from the General Government and that of the State of Iowa and also to discuss the propriety of adopting the Weasle as our National Emblem.

By Order of the Secession Committee 
Copyright of Annals of Iowa is the property of State of Iowa, by \& through the State Historical Society of Iowa and its content may not be copied or emailed to multiple sites or posted to a listserv without the copyright holder's express written permission. However, users may print, download, or email articles for individual use. 